\title{
The impact of the EU accession process and $E U$ funding on the professionalization of national interest groups: the Slovenian case
}

\author{
William A. Maloney ${ }^{1}$ - Mitja Hafner-Fink ${ }^{2}$. \\ Danica Fink-Hafner ${ }^{2}$
}

(C) The Author(s) 2018. This article is an open access publication

\begin{abstract}
This article investigates the extent to which European Union (EU) accession and EU funding contribute to the professionalization of interest groups in Slovenia. Have EU accession and funding had a more profound impact on the professionalization of interest groups in Slovenia than the shift from socialism to capitalism? Our novel empirical evidence is drawn from two surveys of interest groups in Slovenia - the first in 1996 eight years prior to Slovenia's membership of the EU (in 2004) and the second in 2012 eight years after its accession. Our findings show that EU accession and funding accentuate the professionalization of interest groups. However, these processes are intertwined with the partitocratic role of national political parties and parties mediate the shape and structure of interest group professionalization via their decisions on the allocation of EU funding to groups.
\end{abstract}

Keywords Interest groups · Funding - Professionalization - Democracy · EU · Slovenia

William A. Maloney

william.maloney@ncl.ac.uk

1 Politics, School of Geography, Politics and Sociology, Newcastle University, Newcastle upon Tyne, UK

2 Faculty of Social Sciences, University of Ljubljana, Ljubljana, Slovenia 


\section{Introduction}

The European Commission (EC) has sought to stimulate the active involvement of civil society organizations (CSOs) ${ }^{1}$ in the European policy-making process perceiving these bodies as central democratic partners. The European Union (EU) White Paper on Governance (COM 2001) called for a more engaged and vibrant European civil society perceiving it not as a luxury but a necessity. It (COM 2001) (re-)emphasized neo-Tocquevillian factors-i.e. the importance of the internal aspects of associational life for the proper functioning of democracy and democratization-and sought to make the policy-making process more open, transparent and participatory. The aim was to create a more democratically balanced process involving the mobilization of a wider and more diverse range of interests from differing institutional and territorial levels-e.g. Eurogroups to local groups and organizations from Western, Southern, and Central and Eastern Europe (CEE). Increasing pluralism and greater associational vibrancy are seen as helping to bridge the 'democratic deficit' by bringing citizens closer to the EU, enhancing European integration, fostering European identity, and increasing the legitimacy of the EU. However, the implementation of these strategic objectives has a palpable impact on the structure and professionalization of interest groups systems in Europe.

While much of the EU's civil society promotion activities and financial support (EU programmes or structural fund, e.g. Tacis, Phare, European Social Fund) have been endeavouring to strengthen democracy, there is a professionalization externality. For example, Sanchez-Salgado (2011: 5; 9) argues that EU funding has facilitated the growth of professionalization; it may also help some organizations become more influential at the expense of the less fortunate who fail to secure such support. Groups may perceive professionalization as an effective way to develop a viable and sustainable organization and a means to increase their policy influencing capacities. However, stimulating organizational professionalization via funding has implications for both the 'practice' and 'quality' of democratic politics. For example, as Saurugger (2012) highlighted, the literature on the professionalization of interest groups and CSOs more broadly has shown that professionalization is central to several developments, including: the move from contentious to conventional politics (i.e. outsider to insider politics); the rise of the professional/expert careerist as opposed to the committed amateur; and, somewhat ironically, the simultaneous organizational advocacy for societal-level democratic reform while many professionalized groups eschew internal democratic habits and routines that see members playing a cameo democratic role.

\footnotetext{
${ }^{1}$ We define CSOs as non-state actors that seek to defend and advance citizens' interest by influencing policy outcomes. This encompassing definition includes non-governmental organizations, social movement organizations, trade unions, interest groups and is aligned with the EU's broad perspective on the CSO terrain. In this article, we use the interest group nomenclature. Defining interest groups is not a straightforward task in a heavily contested field replete with a surfeit of types and sub-types. We follow Beyers et al. (2008: 1106) who identify three key aspects: Organization-aggregates of "individuals and/ or organized forms of political behaviour"; Political Interest-aims to influence policy outcomes; and Informality - do not seek to hold public office or compete in elections. Beyers et al. (2008: 1107) conclude, "The combination of these three features makes the population of interest groups rather heterogeneous and often difficult to delineate".
} 
This article investigates the impact of EU membership and EU funding on interest group professionalization in Slovenia. Our research question is: 'To what extent does EU accession and EU funding contribute to the professionalization of interest groups?'. We also investigate if there are any domestic variables that could play a mediating or direct role in the professionalization process? The article makes an original and significant contribution in two main ways. First, it addresses the paucity of research on the effect of EU membership and funding on domestic interest group systems in CEE countries-we directly address this through our focus on Slovenia. ${ }^{2}$ Secondly, we conducted a controlled panel study survey drawing on primary data from the same interest groups at two points in time (1996 and 2012) (It should be emphasized that this is not two independent samples.). We argue that EU accession had a profound impact on the professionalization of interest groups-even larger than the shift from socialism to capitalism. This is primarily because formal EU membership not only instantly opened many new opportunities for Slovenian interest groups to receive EU funding, but also the pot of money available was significantly greater than in the pre-accession phase. It is also important to note that the transition to democracy, which included a liberalization phase, allowed for a gradual adaptation of interest groups to political pluralization and a democratic context.

Slovenia is also an interesting case because in the pre-EU accession phase the interest group system's dependence on external funding was low. Accordingly, the independent effect of EU funding can be more clearly empirically distinguished from other determinants of professionalization in Slovenia than in other recent EU accession countries where the contexts are either blurred or collinear. Furthermore, Slovenia has several distinctive aspects compared to other CEE countries. First, the transition to a capitalist economy and the new liberal-democratic order was smoother. Secondly, in terms of the structure and vibrancy of its interest group system, Slovenia is arguably the closest of all the CEE to its Western European peers. ${ }^{3}$ Thirdly, Slovenia has had comparatively strong trade unions as well as a long (pre-socialist, socialist and post-socialist) neocorporatist tradition.

To answer our research question-To what extent does EU accession and EU funding contribute to the professionalization of interest groups? We analyse empirical data gathered in Slovenia from the same interest groups that were active at two points in time (organizational surveys in 1996 and 2012) (see Fink-Hafner 1996; Fink-Hafner et al. 2012). The 1996 research was conducted 8 years prior to Slovenia's membership of the EU (in 2004) and the 2012 study 8 years after its accession. This panel approach permits a detailed analysis of interest groups active in the pre- and post-accession stages and their access to funding. Theoretically, there are two potential effects on the level of professionalization post-accession. First, between 1996 and 2012 we expect to see a growth in the level of professionalization

\footnotetext{
${ }^{2}$ Slovenia is a post-socialist country with two million inhabitants covering a territory approximately the size of Wales, and it became a full EU member in 2004.

3 While the average level of citizen involvement in associations in Slovenia between 1990 and 2010 does not reach the 'dizzy heights' of the Scandinavian countries or the Netherlands (+ 80\%). However, at $57 \%$ it is slightly below (West) Germany (65\%) and Belgium (62\%), but substantially above Italy (43\%), Hungary (36\%), Spain (36\%) and Greece (30\%) (van Deth and Maloney 2015).
} 
because of increased availability of funding to EU member state interest groups. Secondly, the gap in the level of professionalization may be reduced because more organizations will be able to access these monies. EU funds could in fact level the professionalization playing field and we may see fewer differences albeit at a higher level of professionalization in 2012. The main aspects of our analysis include: (1) the development and comparison of interest group typologies based on various dimensions of professionalization in 1996 and 2012; (2) the development of a composite and standardized measurement of professionalization to compare the general level of interest group professionalization before and after Slovenian accession (panel); and (3) testing the effect of the EU funding on the level of professionalization through the application of multiple linear regression models for both points in time.

\section{Professionalization and EU funding}

The adaptation of interest groups and CSOs in response to a diverse variety of internal and external pressures/incentives has been documented by several scholars (Buth 2013; Císař 2009; Císař and Vrábliková 2009; Fagan 2010; Jordan and Maloney 2007; Maloney 2008; Maloney and Jordan 1997; and Saurugger 2007, 2012). In many instances change has been de facto professionalization. This led to the emergence of Protest Business-type organizations (Maloney and Jordan 1997) with a supporter as opposed to a membership base; a full-time leadership and paid staff that generate income from subscriptions, donations, the sale of goods and services and institutional patronage; a leadership that decides organizational priorities, campaigning strategies and tactics, with supporters having few, if any internal democratic rights; and organizational staff that have expertise and accredited professional qualifications in a diverse range of areas-e.g. finance, law, public relations communication, marketing, recruitment and fundraising. These groups also hire external consultants (Andreassen et al. 2014) and have internal organizational training programmes for their staff (Ossewaarde et al. 2008; Hwang and Powell 2009). This level of professionalization means that they adopt a technocratic and scientific approach to organizational recruitment, maintenance and influencing policy outcomes (see Jordan and Maloney 2007; Klüver and Saurugger 2013; McCarthy and Zald [1987] 1994; Saurugger 2012). Accordingly, in our empirical analyses (below) we measure the level of professionalization via an additive index of five professionalization indicators including the number of fulltime staff (FTE) and several indicators of competence/knowledge-collaboration with external experts, in-house training (policy areas and lobbying) and commissioning or conducting research.

EU funding is central to organizational professionalization. However, this money can have a direct organizational impact. In her sample of CSOs active in the EU Kröger (2016: 118) found that $81.8 \%$ of the environmental groups said '... that being involved in EU policy-making affects the working of their organization'. She (2016: 166-167) also quoted one Anti-Poverty organization, 'We wouldn't exist if the EU didn't exist and our existence at the moment is very much related to the 
support we get from the Commission, from the financial support'. Sanchez-Salgado (2011: 10) argues that EU funding has enticed some groups to change their advocacy priorities. The Spanish NGO Movimiento por la Paz, el Desarme y la Libertad (MPDL) moved its central focus from peace and human rights to humanitarian aid to get access to European funds.

Indeed, public funding may not only stimulate professionalization, it might demand it. Governments may effectively require or even mandate groups to adopt a specific organizational structure by setting standards, rules or codes of conduct leading to the development of a CSO 'cadre'-e.g. as the EU has done. Císar (2009), Císař and Vrábliková (2009) and Carmin (2010) provide evidence from the Czech Republic, Hungary, Poland and Slovakia. Císař and Vrábliková (2009: 155) argue that, by supporting domestic social movement organizations (SMOs) '... the EU directly contributes to their professionalization'. Císař (2009: 22-23; 25) found that many organizations in the Czech Republic were totally reliant on institutional patronage and it directly affected their agendas and demands. While Carmin's (2010: 200) research on environmental NGOs in the Czech Republic, Hungary, Poland and Slovakia led her to conclude that the activities and agendas were '... driven by the approach to governance and funding priorities of the European Commission'.

It is worth emphasizing that even though the level of CSO professionalization in post-socialist countries is less pronounced, the process began prior to EU membership. There are pre- and post-EU accession factors and country variations in post-socialist regimes (just as there are in Western European polities). There are also differences in the nature of the professionalization process between various types of interest groups within national systems. However, within Western and CEE member states there may also be some copying of professionalized organizational structures, processes and strategies because these are perceived as highly likely to deliver success in both organizational maintenance and influencing policy outcomes. Interest groups have two axiomatic and interdependent raison d'être: effective representation that leads to policy-making influence; and organizational survival-as Wilson ([1974], 1995: 10) famously noted, 'Whatever else organizations seek, they seek to survive'. Accordingly, it is not surprising that aspiring groups seeking greater riches and policy success choose to adopt an organizational structure akin to those groups perceived as highly successful-i.e. the highly professionalized cohort. The key assumption is that certain characteristics and organizational structures are more likely to deliver success.

We analyse the extent to which EU funding (and EU accession) (independent variable) contribute to the professionalization (dependent variable) of interest groups in Slovenia. Our main theoretical hypothesis is that EU funding has a direct and positive impact on interest group professionalization. Our subsidiary hypothesis is that the impact of EU funding on differences in level of professionalization will be weaker post-accession (drawing on our panel data from 1996 and 2012). We expect this to be the case because Slovenian groups had limited access to EU funding in the pre-accession era and in the post-accession period the overall level and availability of (EU) funds was greater. Accordingly, we expect higher level of professionalization in 2012 but at the same time we expect EU funding to be a 
weaker predictor of differences related to interest group professionalization in Slovenia.

Before our empirical analysis of the impact of EU accession and funding, we need to understand the contextual background of the Slovenian interest group system. Importantly, are there any crucial domestic variables that could play an important mediating role in this process? (See also, Mungiu-Pippidi 2013; Fazekas et al. 2013; Dimulescu et al. 2013).

\section{The Slovenian interest group universe and EU accession}

Slovenia has a long established and vibrant associational life dating back to the Nineteenth century (see, Kranjc 1986; and Stanojević 2010). However, it experienced periods of dictatorship between WWI and WWII and the succeeding authoritarian (Yugoslavian) socialist regime. Slovenian interest groups had very few policy-making participation opportunities until the 1980s because the ruling elite discouraged political pluralism. Despite such constraints many groups emerged from the bottom-up in addition to those established top-down by the regime and the focus of their activities was largely voluntary work. Under the socialist system, policy relevant interest group activities were filtered in several ways and there was the de facto compulsory accession of interest associations into the umbrella organization - the Socialist Alliance of the Working People (SAWP). The SAWP was charged with preparing consensual political opinions and proposals under the leadership of the League of Communists (which was also a member of the SAWP) for sessions of legislative bodies. However, there were some notable highly professionalized organizations-e.g. the League of Veterans of the National Liberation War, trade unions and the Chambers of Commerce. It is relatively unsurprising that reformed (former socialist) trade unions and the Chamber of Commerce retained their resource base (including real estate property) and power after the transition to democracy. However, by the 1990s trade unions faced increased competition due to the establishment of new unions and the Chamber of Commerce lost both its agenda-setting power to propose bills and (subsequently) its official monopoly as the representative of business interests.

Slovenian interest groups also had to adapt to new welfare policies in the 1990s and the transformation of the welfare regime was an important domestic factor in the professionalization process. Economic liberalization permitted the creation of new non-profit organizations and stimulated organizational professionalization via new state-funded contracts for social services (Kolarič et al. 2002, 2009). The overall direction of the new political system evolved closely in line with the general post-socialist tendency towards partitocracy-similar to other third wave democratization countries (Linz 1990; Morlino 1996; Lewis 2000; Magone 2014). In the early stages of the democratization process, many interest groups were ideologically divided in line with the main ideological party cleavages (communist vs anticommunist) (Fink-Hafner 1998).

In Slovenia liberalization and modernization began in the early 1980s, allowing for the mushrooming of new autonomously organized interest groups. During the second 
half of the decade the Slovenian constitution was gradually amended leading to multiparty elections in 1990. During this stage, both old socialist and new post-socialist organizations had to adapt to new circumstances, including increased competition. The growing power and policy impact of trade unions during the 1990s led to the emergence of neo-corporatism. Although Slovenia became an independent state in 1991 it very quickly oriented itself towards European integration and became a full EU member in 2004. All these developments reshaped the interest group environment. However, full EU membership was a step change that significantly change the milieu. Almost 'overnight' the funding opportunities available to Slovenian groups increased.

\section{The professionalization of the Slovenian interest group systems in 1996 and 2012}

\section{Research design, data, and methods}

As outlined above, our main research question addresses the impact of the EU accession process and funding on the professionalization of interest groups in Slovenia. As our data includes information on a wide variety of organizations, we draw on a broad operationalization of professionalization. In line with our theoretical perspective, our operationalization extends beyond paid staff, funding etc. It encompasses other professionalization indicators including, in-house professional training, collaboration with external experts and the commissioning or conducting research. In a first step, we analyse interest group professionalization at two points in time that are equidistant from Slovenia EU accession. Following this we test the extent to which the EU has had an impact on interest group professionalization in Slovenia.

We begin by seeking to identify any professionalization-type changes during the accession process-i.e. both the level of professionalization and the population structure (typology of interest groups regarding the key aspects of professionalization). We use hierarchical cluster analysis to scan the interest group population structure based on empirical data in 1996 and 2012. In a second step, we test the influence of EU funding on the professionalization of interest groups.

Our data are drawn from two face-to-face standardized surveys of 70 and 97 interest group representatives in 1996 and 2012, respectively (Fink-Hafner 1996; Fink-Hafner et al. 2012). The organizations were selected according to their visibility and lobbying activity-i.e. only visible and active organizations were surveyed. Organizations were selected on the basis of the results of previous empirical research (Zajc 1994; Zajc et al. 1991, 2008) and additional consultations with scholars and experts in the relevant policy sectors. Our research is not conducted on a sample of interest group population in Slovenia, but rather on all organizations identified as active in eleven policy fields at both points in time. ${ }^{4}$ The

\footnotetext{
${ }^{4}$ In 1996 a population of 104 active organizations was identified, all were invited to cooperate in the survey and finally 70 organizations responded (67.3\% response rate). In 2012 a population of 109 active organizations was identified, and 97 organizations took part in the survey (90.7\% response rate). The
} 
Table 1 Interest groups in the panel according to the number of full-time paid staff (FTE)

Data source: Formation of Policy Network and Lobbying in Slovenia 1996 and 2012 (FinkHafner 1996; Fink-Hafner et al. 2012)

\begin{tabular}{lllllr}
\hline No. of FTE & \multicolumn{1}{l}{1996} & & \multicolumn{2}{l}{2012} & \\
\cline { 2 - 3 } \cline { 6 - 6 } & IG Freq. & IG $\%$ & & IG Freq. & IG \% \\
\hline Without FTE & 12 & 23.1 & & 10 & 19.3 \\
Up to 2 FTE & 15 & 28.9 & & 5 & 9.6 \\
3-5 FTE & 11 & 21.2 & & 13 & 25.0 \\
6-10 FTE & 5 & 9.6 & & 11 & 21.2 \\
11-15 FTE & 2 & 3.8 & & 4 & 7.6 \\
Above 15 FTE & 7 & 13.4 & 9 & 17.3 \\
\hline
\end{tabular}

questionnaires used in 1996 and 2012 were largely identical—the 2012 questionnaire was adapted to take account of EU membership. To allow cross-time comparison and observation of changes on the level of individual interest groups both data sets (1996 and 2012) were merged to create a panel of the 52 organizations that participated in both projects (and for which valid data for relevant variables were available). In terms of organizational type, the respondents included, professional societies, various chambers and the league of agriculture cooperatives, trade unions, associations representing people with particular diseases and disabilities, and several public interest groups and other social organizations-e.g. tenants, students. The surveys included professionalized and non-professionalized organizations: (a) in 1996 there were 12 organizations without any employees and 7 organizations with more than 15 FTE; (b) in 2012 there were 10 organizations with no employees and 9 organizations with more than 15 FTE (Table 1).

Our general analytical model contains two main phenomena (variables) related to interest groups in Slovenia-professionalization and the EU accession process.

1. The professionalization of interest groups is the dependent variable in the model. It is measured through various indicators of professionalization and covers the main aspects: (a) staff employment and (b) competences (knowledge). The indicators include:

(a) Number of full-time equivalent (FTE) staff;

(b) Answers to the following questions about activities in the last 2 years:

- To what extent has your organization collaborated with external experts, measured on the 5-point scale from 1 (never) to 5 (continuously);

- How much time has your organization devoted to in-house professional training of staff in the core field of its activity (i.e. keeping up to date with policy developments), measured on the 5-point scale from 1 (no time at all) to 5 (a lot of time);

Footnote 4 continued

following eleven policy fields were covered in the survey: economic, social, housing, agricultural, disability, environment, health, education, culture, sports and marketing/public relations. 
- How much time has your organization devoted to the in-house training of staff on effective lobbying strategies and tactics, measured on the 5-point scale from 1 (no time at all) to 5 (a lot of time);

- How much time has your organization devoted to the commissioning or conducting research, measured on the 5-point scale, from 1 (no time at all) to 5 (a lot of time).

The principal component analysis confirmed our expectations that all five indicators were located in the same dimension: in both time points only one component had an eigenvalue higher than 1 (KMO in both time points was higher than 0.65). To measure the level of professionalization, an additive index of five professionalization indicators was created (with acceptable reliability level: Cronbach's alpha in 1996 was 0.71 and in 2012 it was 0.64). When computing the index, the number of FTE had the same weight as the other four indicators taken together: the scale for the number of FTEs ranged from 0 (no FTE) to 16 (or more FTEs), the scale for each of the other four indicators ran from 0 (no time, never) to 4 (a lot of time, permanently). Finally, the index was 'standardized' on the scale from 0 to 10.

The first step of the analysis took an inductive approach by 'scanning' the interest group population structure at 1996 and 2012 using the five indicators (dimensions) of professionalization outlined above. This led to the development (via hierarchical cluster analysis) of two discrete interest group typologies for the 1996 and 2012 samples.

2. EU Funding is the main explanatory phenomenon (independent variable). The key research question is: To what extent does EU funding directly affect the interest group professionalization process? It is hypothesized as having a direct and positive impact on interest group professionalization and is included in the model in two ways:

- As a 'temporal dimension' in the comparative design-comparing interest group professionalization before (1996) and after Slovenian EU accession (2012). Given that we do not have time-series data, we can only observe two time points. In fact we have a 'natural' quasi-experimental design: (a) we observe the same 52 interest groups in 1996 and 2012 and have two measurements (variables) of the professionalization level; (b) between both measurements Slovenia joined the EU and we assume that this change has an impact on the professionalization level; (c) however, unlike in real experimental design, we cannot keep other possible factors fixed and we do not have a control group (organizations not experiencing EU accession), hence our use of the quasi-experimental design label; and

- As a dichotomous variable 'EU funding', the survey question asked if organizations had received income (simply yes or no) from EU sources (e.g. Tacis, Phare, European Social Fund). This was analysed in linear regression models for 1996 and 2012 as our main predictor of interest group professionalization. 
Organizational maintenance and professionalization is dependent on numerous financial sources. In the survey, we asked about 19 types of resources (EU funding was only one) and about the three key sources. Data for 2012 show that among the 52 organizations only one group (a small trade union) receives funds from only one source-membership fees. Whereas, $90 \%$ of organizations receive funds from at least four different sources including, membership fees, sponsorship, state budget, commercial activities, conference fees, EU funds, contract with the government, and lottery.

In the second step, we conducted a linear regression analysis on the 1996 and 2012 data: (a) the level of professionalization (measured with the professionalization index) was included in the regression model as a dependent variable; and (b) the financing of interest groups from EU Funds was included as a main independent variable (predictor). At both points in time the effect of EU finance was controlled for by including other possible factors of professionalization. In line with several observations in the interest group literature on 'control variables' and more recent arguments related to the potential impact of national contextual factors on the distribution of EU funds to specially selected interest groups (see Mungiu-Pippidi 2013; Fazekas et al. 2013; Dimulescu et al. 2013). The model included the following four additional independent variables: (1) (non)economic interest group; (2) interest group-political party alliances; (3) ownership of business premises; and (4) interest group age prior to transition. In order to test how 1996 professionalization affected the 2012 level we added one additional model using the level of professionalization in 1996 as an additional predictor of professionalization in 2012.

\section{Findings 1: temporal similarities and differences in typologies of interest group professionalization}

In this section, our findings from two different analyses are presented. First, we compared the structure of interest groups at both time points (types of interest groups with regard to the level of professionalization) - and using our panel dataalso shifts in interest group type between 1996 and 2012. Second, we analysed changes in the general level of interest group professionalization between 1996 and 2012.

As outlined above, to observe the interest group population structure according to the level and type of professionalization we developed typologies based on the five key indicators of different dimensions of professionalization and a hierarchical cluster analysis of 52 organizations. Groups can be high on some dimensions of professionalization and low on others, and we also have some organization that are high on several measures of professionalization. The hierarchical cluster analysis identifies differences and similarities between interest groups across these five indicators. It then classifies them according to their similarities. Ward's ${ }^{5}$ method

\footnotetext{
5 Ward's method relies on an analysis of the variance approach to assess the distance between clusters. At each step, it seeks to join clusters (objects that are clustered) to minimize the increase in the error sum of squares of group means (see Ward 1963).
} 
was used for clustering, while the squared Euclidian distance for standardized data was used to measure the (dis)similarities among the cases (interest groups). The number of clusters was fixed by cutting the classification tree at the same point (the relative distance between the cases combined into a cluster) for 1996 and 2012 which generated four interest group clusters in 1996 and five in 2012 (see Table 2). At both time points, we have two extreme clusters. First, one with values above the average for all five indicators of professionalization-labelled 'Highly professionalized' (including trade unions, a chamber, students' organization, association of paraplegics _ - and a second with values below the average for all five indicatorscalled 'Amateurs' (e.g. leisure time groups, the association for solar energy, some organizations of professions). The gap between the highly professionalized and all the other types is wider in 1996 (the average difference between the mean of highly professionalized cluster and the means of the others is 5.40). In 2012 the average difference is 3.40. In general, we see a significant increase in the overall level of professionalization overtime: the average value measured by index of professionalization increased from 3.67 (Std. error of Mean $=0.32$; Std. deviation $=2.33$ ) in 1996 to 4.61 (Std. error of Mean $=0.33$; Std. deviation $=2.40$ ) in 2012 (Table 2). We also see that the two professionalized clusters in 2012 ('highly professionalized' and 'staff-rich') include more interest groups than their two counterparts in 1996 ('highly professionalized' and 'semi-professionalized'). This provides support for our thesis that EU accession has contributed to the professionalization of Slovenia interest groups.

The data not only show an increase in the overall level of professionalization, but also greater variation. This is clear from the increase in the different types of interest groups between 1996 and 2012-mostly related to the increased diversification of types between two extremes (i.e. highly professionalized and amateur groups, Table 1). One of the major changes is the emergence of the 'staff-rich' group cluster with surprisingly average professionalization in terms of the other professionalization measures. Staff-rich groups include several trade unions and medical professional associations, chambers of commerce and international charitable organizations. These groups employ highly professional staff with policy relevant and lobbying/advocacy expertise and in all likelihood do not need to rely on external expert collaborations or internal staff training programmes to the same extent as other less staff-rich organizations-hence their lower overall professionalization score in our model.

Since our analysis is based on panel data, we are both able to observe changes between 1996 and 2012 at aggregate level and also how individual interest groups changed their position in the typology in the same period. Based on simple bivariate cross-tabulation, we can see that the two main 1996 clusters that split to the greatest extent were the semi-professionalized and amateur, and that two new (2012) clusters emerged-staff-rich and research-oriented interest group types (see Fig. 1). At the same time, we see that the groups in the highly professionalized cluster in 1996 have maintained this position in 2012. These organizations are located in the 'highly professionalized' or 'staff-rich' clusters. On the 'amateur' side, interest groups have taken much more diverse trajectories with the majority (17 of 26) being found in three 2012 'amateur' clusters (see Fig. 1). All-in-all, it is the staff-rich cluster in 


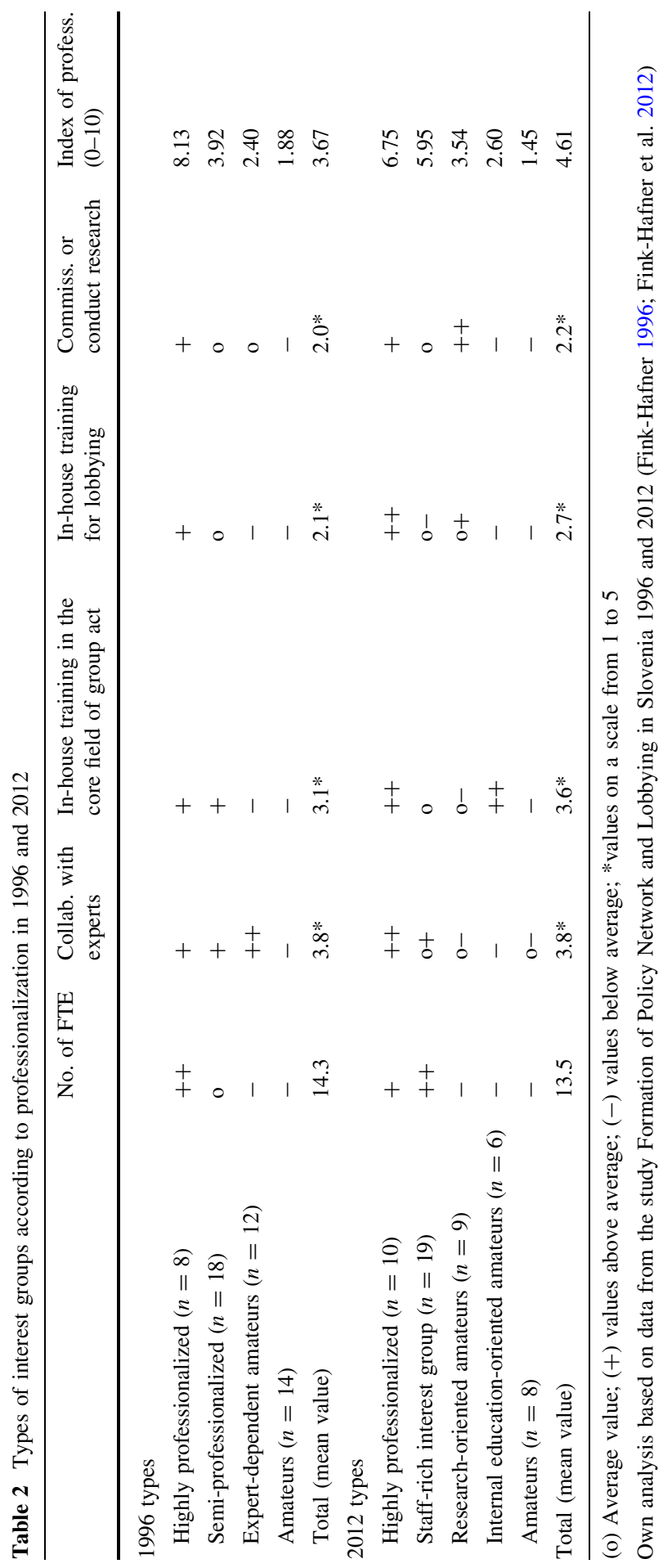




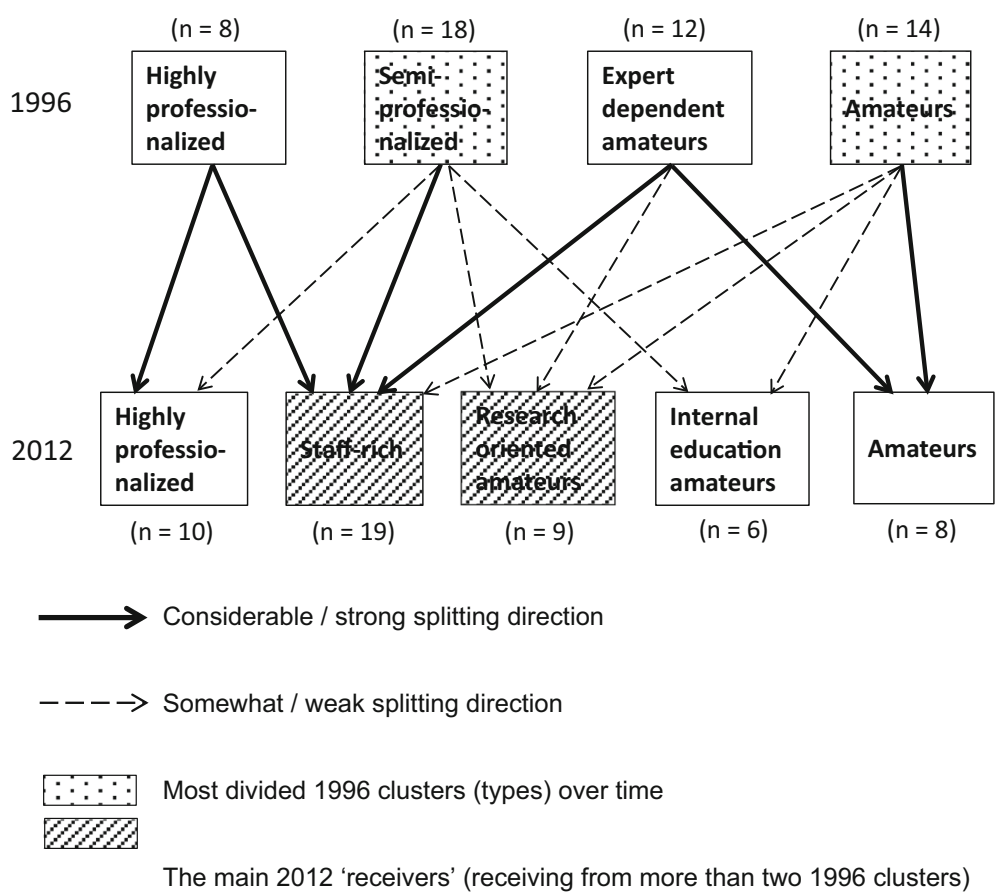

Fig. 1 Moving from the 1996 interest group types to the 2012 interest group types

2012 that grew with interest group shifts from all the 1996 clusters except the 'Amateurs'. While the majority of groups increased their values in the index of professionalization, four of them (e.g. the Union of Ecological Movements of Slovenia, and the Association of Tenants of Slovenia) remained on the same level and eleven declined (with the biggest losers including the League of Paraplegics of Slovenia, the Red Cross umbrella organization, and the League of Consumers of Slovenia). The groups that gained the most in the index of professionalization included: the League of Societies of Pensioners of Slovenia; the new Confederation of Trade Unions 90 of Slovenia; ALTRA-the Committee for Innovations in Mental Health).

\section{Finding 2: the impact of EU funding on interest group professionalization}

The effect of EU funding on the level of interest group professionalization was tested in two steps. First, at each point in time separately by using bivariate analysis (comparing means). Second, by multivariate linear regression analysis including four control variables that were identified in the theoretical section as relevant mediators of the impact of the EU on interest group professionalization-interest group type (economic, non-economic), linkages with a political party (political 
party invitations to interest groups to form an alliance ${ }^{6}$ ), resources (ownership of business premises), and age (before the transition).

As noted above, interest groups do not rely solely on a single financial source. Therefore, we did not expect that European funds would be the only source that could foster professionalization. In order to determine which other income sources might have an impact, we first tested the relationship between professionalization and sources of funding.

In the first step, we tested bivariate associations between professionalization (separately for the typology and the index of professionalization) and funding sources. When applying cross-tabulation for the typology of professionalization and comparison of means for the index of professionalization, we detected both positive and negative associations:

(a) 'Positive' Associations - a higher level of professionalization is more likely when the following sources are present: income from commercial activities, EU funds, and membership fees from organizations

(b) 'Negative' Associations - a lower level of professionalization is more likely when the following sources are present: sponsorship, individual membership fees, contributions of individuals, local community (municipality) budget, and charity events.

Due to the low number of cases $(n=52)$, we cannot include a high number of independent variables in our regression models. We selected independent variables based on our main hypothetical starting point regarding the influence of EU funding and also on the bivariate analysis (outlined above). When we include sources of funding, those with asymmetrical distributions were excluded in the regression model as predictors for the professionalization level. At both time points, only two variables were statistically significant $(p<0.05)$ with high standardized regression coefficient $(\beta>0.3)$ : EU funds and own sources. Accordingly, we included 'funding from own sources' as a fifth control variable in the final regression model.

The relationship between interest group professionalization and EU funding is clear at the bivariate level. At both points in time, the average values of the professionalization index for interest groups receiving financial resources from EU funds are 6.70 in 1996 and 5.52 in 2012. These are significantly higher than the average values for the interest groups without EU funding (3.03 in 1996 and 3.50 in 2012, see Fig. 2). As discussed above the level of professionalization (index) increased from 3.67 to 4.61 in the 1996-2012 period.

However, is it the same predictors at both points in time? We sought to answer this question with the help of multiple linear regression analysis. The data show that even when controlling for other possible effects in the framework of the regression models (1.1 and 2.1) in 1996 and 2012 EU funding emerges as a statistically significant predictor of professionalization (Table 3). ${ }^{7}$ However, there is an

\footnotetext{
6 The survey question was: Have any political parties looked for an alliance with your organisation/group in respect of an individual case? (1-yes; 2-no; 9-don't know, cannot estimate; 0-n.a.).

7 We also used other methods (analysis of variance, logistic regression) which suggested the same conclusion.
} 

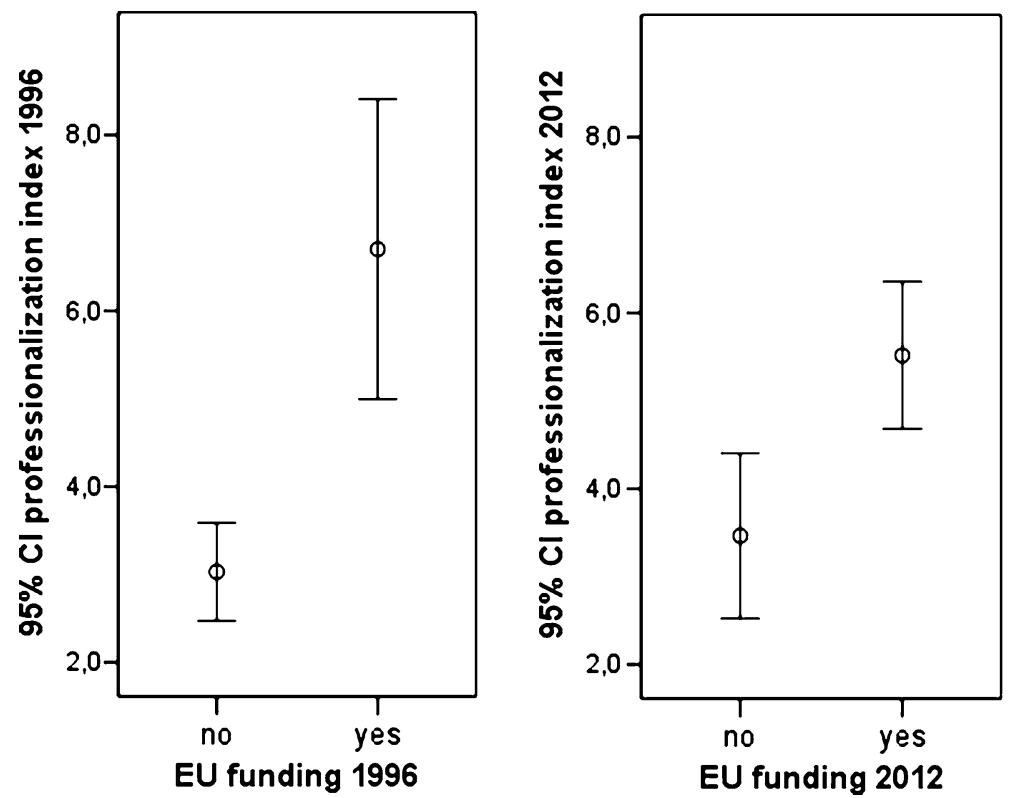

Fig. 2 Level of professionalization and EU funding of interest groups (mean values of professionalization index measured on the scale from 0 to 10 )

important difference between 1996 and 2012. Regression coefficients show that in 1996 only EU funding $(\beta=0.539)$ and an interest group's own commercial sources $(\beta=0.326)$ are statistically significant predictors $(p<0.10)$. While in 2012 five independent variables are significant $(p<0.10)$ : EU funding, ownership of business premises, funding from own commercial sources, linkages with a political party, and economic interest groups (Table 3). EU funding appears to be less important in 2012 than 1996. However, this is largely because there were more EU funds available to Slovenian interest groups after EU accession. The number of organization in receipt of EU funding in 1996 and 2012 was 9 and 29, respectively. So we have a higher overall level of professionalization because of the greater availability of funds, but the differences between organizations relate to other domestic factors (e.g. political party linkage or organizational characteristics) more than EU finding. Once we add the level of professionalization in 1996 to the 2012 model, then the predictive power of the same five predictors changes slightly: (a) the predictive power of EU funding $(\beta=0.287)$ and being an economic interest group $(\beta=0.211)$ increases marginally; and (b) the predictive power of being in an alliance with a political party, ownership of business premises, and funding from own commercial sources decreases significantly. Furthermore, the professionalization level in 1996 is the main predictor of the professionalization in 2012 $(\beta=0.422)$ - highly professionalized interest groups in 1996 have higher levels of professionalization in 2012 (Table 3, Model 2.2). The result indicates that professionalization should be understood as a process that EU accession and 
Table 3 Predictors of interest groups' professionalization-linear regression with regression coefficients $(B)$ and standardized regression coefficients $(\beta)$ (models for 1996 and 2012)

\begin{tabular}{|c|c|c|c|c|c|c|}
\hline & \multirow{2}{*}{\multicolumn{2}{|c|}{$\frac{1996}{\text { Model } 1.1}$}} & \multicolumn{4}{|l|}{2012} \\
\hline & & & \multicolumn{2}{|c|}{ Model 2.1} & \multicolumn{2}{|l|}{ Model 2.2} \\
\hline & $B$ & $\beta$ & $B$ & $\beta$ & $B$ & $\beta$ \\
\hline Intercept & 2.462 & & 1.689 & & 1.670 & \\
\hline EU funding & 3.254 & $* * * 0.539$ & 1.322 & $* * 0.277$ & 1.374 & $* * 0.287$ \\
\hline Alliance with a political party & -0.179 & -0.038 & 1.271 & $* * 0.251$ & 0.887 & $* 0.175$ \\
\hline Economic interest group & 0.399 & 0.086 & 0.941 & $* 0.198$ & 1.004 & $* * 0.211$ \\
\hline Ownership of business premises & 0.276 & 0.058 & 1.628 & $* * * 0.343$ & 1.069 & $* * 0.225$ \\
\hline $\begin{array}{l}\text { Funding from own commercial } \\
\text { sources }\end{array}$ & 1.553 & $* * 0.326$ & 1.346 & $* * 0.273$ & 0.903 & $* 0.183$ \\
\hline Established before 1988 & -0.250 & -0.054 & -0.763 & -0.160 & -0.412 & -0.087 \\
\hline Professionalization in 1996 & - & - & - & - & 2.544 & $* * * 0.422$ \\
\hline$N$ & 51 & & & 52 & & 52 \\
\hline$F$ & $7.102 * * *$ & & & $8.258 * * *$ & & $12.832 * * *$ \\
\hline Adjusted $R^{2}$ & 0.423 & & & 0.461 & & 0.619 \\
\hline
\end{tabular}

All independent variables were binary (0-absence; 1-presence). Professionalization in 1996 was dichotomized with the threshold in the middle of the 10-point scale. We have analysed a 'sample' that is a 'population' of visible and active organizations. This is why p values do not actually represent error probabilities when making inference from sample statistics to population parameters. We only treat them as additional information about the strength and the importance of effects represented by regression coefficients

Own analysis based on data from the study Formation of Policy Network and Lobbying in Slovenia 1996 and 2012 (Fink-Hafner 1996; Fink-Hafner et al. 2012)

$* * * p<0.01 ; * * p<0.05 ; * p<0.10$

funding accentuate. The influence of the initial level of professionalization also indirectly increases the 2012 professionalization level. Additional bivariate and multiple regression analyses indicate that the indirect influence goes via: (1) party linkages (the 1996 professionalization level affects interest group-party linkages in 2012, and interest groups with party linkages get better access to EU funding); and (2) economic resources (the 1996 professionalization affects the 2012 interest group ownership of business premises which further increases professionalization). The professionalization of interest organizations in receipt of EU funding becomes a virtuous circle for these groups-professionalization begets professionalization.

The data on interest group-political party linkages show, that in 1996 and 2012, 22 and 17 interest groups, respectively, had links with political parties. Interest groups with party linkages at both points are generally those with large numbers of members and mostly highly professionalized (e.g. trade unions, Chamber of Commerce, the league of pensioners' societies), and/or well-placed to contribute to policy-making and the implementation of particular policies (e.g. in the housing and environmental fields). In both models, political party linkages in 2012 appear to be important. Accordingly, we conducted an additional bivariate analysis of the 
association between national political party linkages and EU funding. This association is statistically significant $\left(\chi^{2}=7.236 ; \quad d f=1 ; p<0.01\right.$; Cramer's $\mathrm{V}=0.373$ ): $82.4 \%$ of interest groups (14 out of 17 ) linked to a political party were in receipt of EU funding. While among those groups not affiliated to political parties, EU funding was present in only $42.9 \%$ of cases (15 out of 35). It appears that party linkages affect the level of professionalization not only directly as can be seen from the regression model (Table 2), but also indirectly through EU funding. In addition to this, participants in the stakeholder meeting we organized also stressed that excellent links to, and good working relationship with political parties was crucial to the securing EU funding. Our findings are in line with recent research that highlighted national political parties' ability to extract significant resources from the state (Rupnik and Zielonka 2013: 13-14) and that EU funds add to the pool of particularistic allocated public resources (Mungiu-Pippidi 2013). Based on the existing case studies, it seems that national political parties can and do have a mediating influence on the distribution of EU funds to national organizations-as also suggested by Mungiu-Pippidi (2013), Fazekas et al. (2013) and Dimulescu et al. (2013). However, as shown in the case of Slovenia-the previously existing level of interest group professionalization sets the national group landscape, which may be further boosted by EU funds.

In general, our analyses show that EU funding is an important factor (predictor) of interest group professionalization. While there is higher probability of higher levels of professionalization in cases where EU funding is present, it does not follow that EU monies are the sole driver of interest group professionalization. Data for 2012 show that:

(a) among 19 organizations from the 'staff-rich' cluster only $4(21.1 \%)$ say that EU funds are a key source;

(b) among 10 organizations from 'highly professionalized' cluster only two organizations say that EU funds are their key source.

Each of these 'highly professionalized' or 'staff-rich' organizations with EU funds as their main source has at least four additional income sources (e.g. government agencies, membership fees, commercial income, and sponsorship). If we look at all income sources the majority of highly professionalized organizations (over $70 \%$ ) receive EU funds, while only $35 \%$ of organizations from three 'amateur' clusters get EU money.

\section{Conclusions}

The findings in this article are in line with our main hypothesis that we expected to see an increase in the level of professionalization between 1996 and 2012-largely because of EU accession and the greater availability of EU funds. However, our analysis showed that there was a larger differentiation in interest group type in terms of professionalization-i.e. the differences in professionalization among interest groups are lower in 2012 than 1996. This confirms our subsidiary hypothesis that the 
impact of EU funding on differences in levels of professionalization would be weaker post-accession.

Our research demonstrated that EU accession and funding affects the national interest group professionalization process. Our panel data analysis revealed that the population of active interest groups in the eleven policy fields studied in Slovenia has been changing dramatically in terms of the level of professionalization. Based on a more refined and theoretically informed definition of professionalization (going beyond simply equating professionalization with the number of full-time staff) various interest group types emerged in the 1996 and 2012-four in 1996 and five in 2012. Additionally, EU accession and funding had an important impact on interest group adaptation (There are reasonable grounds to assume this impact is being felt across the entire interest group universe in Slovenia.)

The overall trend in the interest group system has been towards increasing professionalization (the average value of the index increased from 3.7 in 1996 to 4.6 in 2012). There was a greater density of professionalized organizations in 2012, staff-rich interest groups emerged; and many of the amateur-type groups identified in 1996 were embracing several aspects of the professionalized approach to organizational maintenance, structure and lobbying/advocacy in 2012.

Although 'the EU factor' has proven to be among the main predictors explaining interest group professionalization in Slovenia, it was not the only one. Interest group-party political linkages were also an important predictor in 2012. Indeed, the impact of the EU was mediated by national factors. The empirical findings highlight the peculiar inter-linkage of domestic post-socialist political context (with its partitocratic tendencies) and party-related clientelism as variables that filter the EU's impact on domestic interest group professionalization. After Slovenian accession political parties played an important mediating role in the distribution of EU funds.

Our findings are in line with Sanchez-Salgado (2011: 17) and suggest that EU funding (and accession) has a significant impact on the structure of civic organizations. Our findings also connect to the literature that highlights the intervening role of political parties in post-authoritarian political systems (Magone 2014), especially with regard to the filtering of EU professionalization impacts. The key conclusion is not only that domestic contextual factors in general, but national political parties in particular, interpose and mediate the Europeanization process in the field of interest groups and that they do that via control of the dissemination of EU funds. This type of relationship may also exist in other countries with partitocratic national decision-making on allocation of EU funds. In the time honoured academic tradition, additional research is needed to assess the extent to which these findings are more widely generalizable.

Open Access This article is distributed under the terms of the Creative Commons Attribution 4.0 International License (http://creativecommons.org/licenses/by/4.0/), which permits unrestricted use, distribution, and reproduction in any medium, provided you give appropriate credit to the original author(s) and the source, provide a link to the Creative Commons license, and indicate if changes were made. 


\section{References}

Andreassen, T.A., E. Breit, and S. Legard. 2014. The Making of 'Professional Amateurs': Professionalizing the Voluntary Work of Service user Representatives. Acta Sociologica 57(4): 325-340.

Beyers, J., R. Eising, and W.A. Maloney. 2008. Researching Interest Groups in Europe and Elsewhere: Much We Study, Little We Know? West European Politics 31(6): 1103-1128.

Buth V. 2013. Speak to Me Only with Thine Ayes? The representativeness of professional EU advocacy groups. PhD Thesis, University of East Anlgia.

Carmin, J.-A. 2010. NGO Capacity and Environmental Governance in Central and Eastern Europe. Acta Politica 45(1/2): 183-202.

Císař, O. 2009. The Diffusion of Public Interest Mobilization: Advocates without Members in the PostCommunist Czech Republic. Unpublished paper.

Císař, O., and K. Vrábliková. 2009. Transnational Activism of Social Movements Organizations: The Effect of European Union Funding on Local Groups in the Czech Republic. European Union Politics 14(1): 140-160.

COM. 2001. European Governance: A White Paper, 25.07.2001. Brussels: CEC.

Dimulescu, V., R. Pop, and I.M. Doroftei. 2013. Corruption Risks with EU Funds in Romania. Romanian Journal of Political Science 13(1): 101-123.

Fagan, A. 2010. The New Kids on the Block-Building Environmental Governance in the Western Balkans. Acta Politica 45(1/2): 203-228.

Fazekas M., Chvalkovska J., Skuhrovec J., Tóth I.J. and King, L.P. 2013. Are EU Funds a Corruption Risk? The Impact of EU Funds on Grand Corruption in Central and Eastern Europe'. In ERCAS Working Papers, No. 39, November 2013. http://www.againstcorruption.eu/reports/are-eu-funds-acorruption-risk-the-impact-of-eu-funds-on-grand-corruption-in-central-and-eastern-europe/. Accessed 1st Feb 2016.

Fink-Hafner, Danica 1996. Oblikovanje policy mrež in lobiranje (Formation of Policy Network and Lobbying in Slovenia) (1996). Ljubljana: Fakulteta za družbene vede, Center za politološke raziskave (Faculty of Social Sciences, Centre for Political Science Research), 1996 [datoteka podatkov (data file)]. Distribucija (Distribution): Arhiv družboslovnih podatkov (Social Science Data Archives), November 2001. https://www.adp.fdv.uni-lj.si/opisi/polmr96/.

Fink-Hafner, D. 1998. Preoblikovanje policy omrežij v kontekstu demokratičnega prehoda - slovenski primer. Teorija in praksa 35(5): 830-849.

Fink-Hafner, Danica, Damjan Lajh, Mitja Hafner-Fink, Simona Kustec Lipicer, Alenka Krašovec, Tomaž Deželan, Matej Knep and Meta Novak 2012. Oblikovanje policy mrež in lobiranje v Sloveniji $=$ Formation of Policy Networks and Lobbying in Slovenia (2012) [data file]. Slovenia, Ljubljana: Univerza v Ljubljani = University of Ljubljana, Fakulteta za družbene vede = Faculty of Social Sciences, Center za politološke raziskave = Centre for Political Science Research [production], 2012. Slovenia, Ljubljana: Univerza v Ljubljani = University of Ljubljana, Arhiv družboslovnih podatkov $=$ Social Science Data Archives [distribution], 2016. available at https:// www.adp.fdv.uni-lj.si/opisi/polmr12/povezana-gradiva/.

Hwang, H., and W.W. Powell. 2009. The Rationalization of Charity: The Influences of Professionalism in the Nonprofit Sector. Administrative Science Quarterly 54(2): 268-298.

Jordan, G., and W.A. Maloney. 1997. The Protest Business? Mobilizing campaign groups. Manchester: Manchester University Press.

Jordan, G., and W.A. Maloney. 2007. Interest Groups and Democracy: Enhancing Participation?. Basingstoke: Palgrave.

Klüver, H., and S. Saurugger. 2013. Opening the Black Box: The Professionalization of Interest Groups in the European Union. Interest Groups and Advocacy 2(2): 185-205.

Kolarič, Z., A. Černak-Meglič, and M. Vojnovič. 2002. Neprofitno-volunterske organizacije. Ljubljana: Založba FDV.

Kolarič, Z., T. Rakar, and Mrak A. Kopač. 2009. Slovenski sistem blaginje v procesu postopnega spreminanja. In Starejši ljudje v družbi sprememb, ed. H. Valentina. Aristej: Maribor.

Kranjc S. 1986 Interesna združenja občanov in politični system. Ph.d. thesis. University of Ljubljana, Faculty of Social Sciences, Ljubljana.

Kröger, S. 2016. Europeanised or European? Representation by Civil Society Organisations in EU Policy Making. Colchester: ECPR Press. 
Lewis, P.G. 2000. Political Parties in Post-Communist Eastern Europe. London and New York: Routledge.

Linz, J.J. 1990. Transitions to Democracy. The Washington Quarterly 13: 143-164.

Magone J.M. 2014. Learning To Be Democratic: The Role of Interest Groups On Shaping State-Civil Society Relations In Southern Europe'. Paper presented at the eighth conference of the European Consortium for Political Research, University of Glasgow, pp. 3-7 September 2014.

Maloney, W. A. 2008. The Professionalization of Representation: Biasing Participation. In Opening EUGovernance to Civil Society: Gains and Challenges, ed. B. Kohler-Koch, D. De Bièvre and W A Maloney, 69-85. CONNEX Report Series, No. 5.

Maloney, W.A., and G. Jordan. 1997. Mobilization and Participation in Large-Scale Campaigning Groups in the Britain: The Rise of the Protest Business. In Private Groups and Public Life: Social Participation, Voluntary Associations and Political Involvement in Representative Democracies, ed. J.W. van Deth, 107-124. London: Routledge.

Morlino L. 1996. Which Democracies in Southern Europe?. Università di Firenze, Working Paper no.113, http://www.icps.cat/archivos/workingpapers/wp_i_113.pdf?noga=1. Accessed 1st Feb 2016.

McCarthy J.D. and Zald M.N. (eds) ([1987] 1994) Social Movements in an Organizational Society: Collected Essays, New Brunswick, N.J.: Transaction Publishers.

Mungiu-Pippidi, A. 2013. The Good, the Bad and the Ugly: Controlling Corruption in the European Union', Advanced Policy Paper for the European Parliament. Berlin: Hertie School of Governance.

Ossewaarde, R., A. Nijhof, and L. Heyse. 2008. Dynamics of NGO Legitimacy: How Organising Betrays Core Missions of INGOs. Public Administration and Development 28(1): 42-53.

Rupnik, J., and J. Zielonka. 2013. Introduction: The State of Democracy 20 Years on: Domestic and External Factors'. East European Politics and Societies and Cultures 27(1): 3-25.

Sanchez Salgado R. 2011. EU Structuring Effects on Civic Organizations: Learning from Experience, Learning from Comparison. In IPSA RC32 Conference in Dubrovnik, 10-12 June.

Saurugger, S. 2007. 'Democratic 'Misfit'? Conceptions of Civil Society Participation in France and the European Union. Political Studies 55: 384-404.

Saurugger, S. 2012. The Professionalization of EU's Civil Society: A conceptual framework. In New 'Participatory' Dimensions in Civil Society: Professionalization and Individualized Collective Action, ed. J.W. van Deth, and W.A. Maloney, 69-83. London: Routledge.

Stanojević, M. 2010. Social Pacts in Slovenia. In After the Euro and Enlargement: Social Pacts in the EU, ed. P. Pochet, 317-344. Brussels: European Trade Union Institute-ETUI.

van Deth, J.W., and W.A. Maloney. 2015. Associations and Associational Involvement in Europe. In Routledge Handbook of European Politics, ed. J.M. Magone, 826-842. London: Routledge.

Ward Jr., J.H. 1963. Hierarchical Grouping to Optimise an Objective Function. Journal of the American Statistical Association 58(301): 236-244.

Wilson J.Q. ([1974], 1995) Political Organizations. Princeton, New Jersey: Princeton University Press.

Zajc, Drago, Tomaž Deželan and Danica Fink Hafner 1991. National Assembly of the Republic of Slovenia: Series information [data file]. Slovenia, Ljubljana: University of Ljubljana, National Assembly of the Republic of Slovenia [production]. Slovenia, Ljubljana: University of Ljubljana, Social Science Data Archive [distribution], 2011. (URL: https://www.adp.fdv.uni-lj.si/opisi/dzrs/).

Zajc, Drago 1994. Survey among members of National Assembly [data file]. Ljubljana: Faculty of Social Sciences, Centre for Political Science Research [production]. Ljubljana: University of Ljubljana, Faculty of Social Sciences, Social Science Data Archive [distribution], December 2002. (URL: https://www.adp.fdv.uni-lj.si/opisi/posdz94/).

Zajc, Drago, Tomaž Deželan and Danica Fink Hafner 2008. The attitudes of deputies of the National Assembly of the Republic of Slovenia 2008 [data file]. Slovenia, Ljubljana: University of Ljubljana, Centre for Political Science Research [production]. Slovenia, Ljubljana: University of Ljubljana, Social Science Data Archive [distribution], 2011. (URL: https://www.adp.fdv.uni-1j.si/opisi/dzrs08/). 